\title{
100-YEAR-OLD HAEMATOLOGICA IMAGES: ACUTE HISTIOCYTEMIC SYNDROME OR BLASTIC PLASMOCYTOID DENDRITIC CELL NEOPLASM
}

\section{Carlo L. Balduini}

Ferrata-Storti Foundation, Pavia, Italy

E-mail: CARLO L.BALDUINI - carlo.balduini@unipv.it

doi:10.3324/haematol.2020.249912

A $t$ the beginning of the last century, the nature of leukemia was still the subject of heated discussion. Some authors were convinced that leukemias were neoplastic diseases, while others claimed them to be hyperplastic, reactive illnesses. ${ }^{1}$ Despite this uncertainty, the availability of new methods for staining blood cells and better microscopes stimulated many researchers to try to classify leukemias on a morphological basis.

The two previous covers of Haematologica this year have been dedicated to the articles published in this journal in 1927 and 1928 by Alder and Di Guglielmo who identified by clinical and morphological criteria two 'new' disorders: acute promyelocytic leukemia and pure erythroid leukemia, respectively. ${ }^{2,3}$ The cover image of this issue was taken from one of the figures (Figure 1) illustrating the paper by Ferrata and Reitano entitled 'Sindromi istiocitemiche' (Histiocytemic syndromes) published in Haematologica in 1923. ${ }^{4}$ Based on blood film evaluation of leukemic patients, the authors identified a rare form characterized by the presence of 'tennis racket' cells and a rapidly fatal course. They were inclined to believe that these elements derived directly from very early progenitor cells, which at the time were named hemohistioblasts or Ferrata's cells. ${ }^{5}$ The authors tentatively proposed the name acute histiocytemic syndrome for this new form of leukemia. In 1966, Rappaport introduced the term malignant histiocytosis for this disorder, ${ }^{6}$ which is currently classified as blastic plasmacytoid dendritic cell neoplasm since it has been shown to derive from transformation of precursors of plasmocytoid dendritic cells.?

Figure 2 allows us to compare the 'tennis racket' cells described by Ferrata and Reitano with those reported in the chapter blastic plasmacytoid dendritic cell neoplasm of the Haematologic Atlas of Hematologic Cytology published this year by the Ferrata-Storti Foundation. ${ }^{8}$

The close similarity between the cells of Figures 1 and 2 is obvious. So, we suggest that the merit of having been the first to identify this disorder should go to Ferrata and Reitano.

\section{References}

1. Mazzarello P. One hundred years of Haematologica. Haematologica. 2020;105(1):12-21.

2. Balduini CL. 100-year-old Haematologica images: Acute promyelocytic leukemia. Haematologica 2020;105(2):245

3. Balduini CL. 100-year-old Haematologica images: Di Guglielmo disease or pure erythroid leukemia. Haematologica 2020;105(3):525.

4. Ferrata A, Reitano D. [Sindromi istiocitemiche (emoistioblastiche)]. Haematologica. 1923;4:385-393

5. Baserga A, Zavagli G. Ferrata's stem cells: an historical review on hemocytoblasts and hemohistioblasts. Blood Cells. 1981;7(3):537-545.

6. Rappaport H. Tumors of the hemopoietic system, in Atlas of Tumor

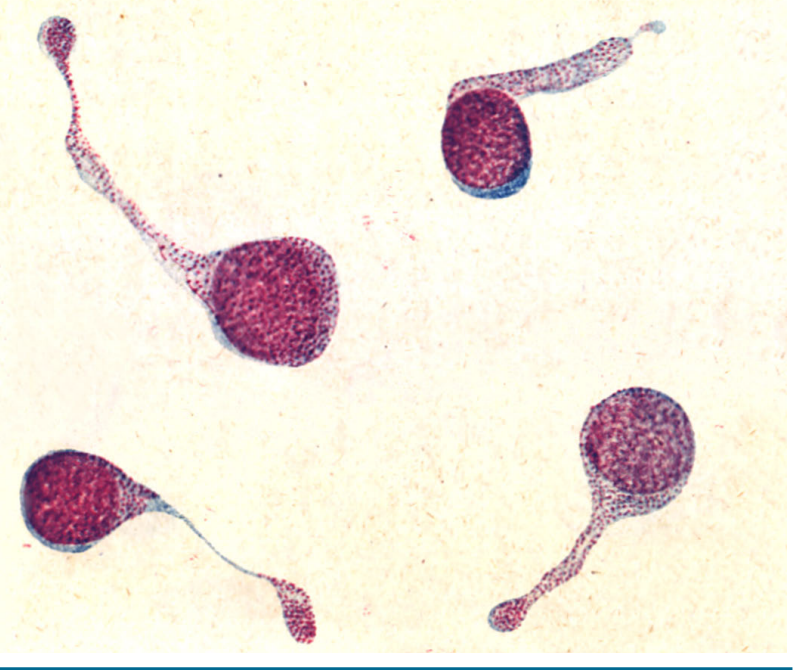

Figure 1. Hand-drawn color plate illustrating the Ferrata and Reitano paper on 'acute histiocytemic syndrome' published in Haematologica in 1923. From the original caption of this figure: 'Leukocytoid cells of histioid origin. Typical cells in the shape of a 'tennis racket'. These cells were observed in the peripheral blood of a patient with an aggressive form of leukemia. The authors concluded that he was affected by a new form they named 'histiocytemic syndrome'.

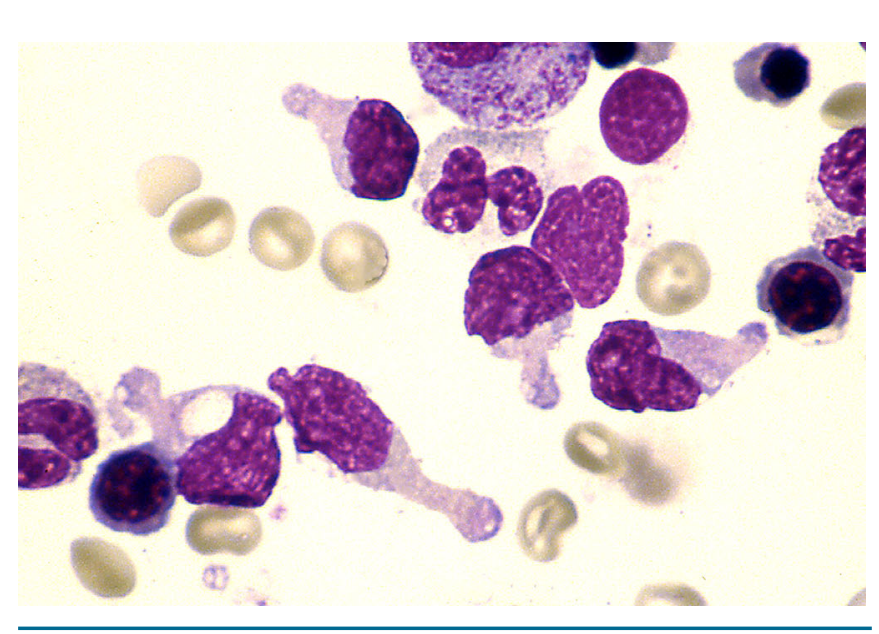

Figure 2. Image with 'tennis racket' cells from a patient with blastic plasmacytoid dendritic cell neoplasm published in the Haematologic Atlas of Hematologic Cytology. ${ }^{8}$

Pathology, p 49. Armed Forces Institute of Pathology, Washington, DC, 1996.

7. Facchetti F, Petrella T, Pileri SA. Blastic plasmacytoid dendritic cell neoplasm. In: Swerdlow SH, Campo E, Harris NL et al (Eds). WHO Classification of Tumors of Hematopoietic and Lymphoid tissues (Revised 4th edition). IARC: Lyon; 2017.

8. Invernizzi R. Blastic plasmacytoid dendritic cell neoplasm. Haematologica. 2020;105(Supplement n 1):120-121. 